\title{
Dietary Inadequacy of Micronutrients in Adolescent Girls of Urban Varanasi: Call for Action
}

\author{
Jaya Krishna and C.P. Mishra*
}

\author{
Department of Community Medicine, Institute of Medical Sciences, Banaras Hindu University, Varanasi- \\ 221005, India
}

\begin{abstract}
Background: Adolescent girls are vulnerable to dietary inadequacy in general and micronutrients (viz, Iron, Calcium, Vitamin $A$ and $C$ etc) inadequacy in particular due to variety of reasons including their own food preferences. Lack of protective foods in their diet can have serious consequences.
\end{abstract}

Objective: To assess dietary inadequacy of micronutrients in urban adolescent girls and to pinpoint their correlates.

Methodology: A community based cross sectional study was undertaken on 400 adolescent girls (10-19 years) of urban
Varanasi, selected by adopting multistage sampling technique. Their socio-demographic and personal characteristics
were obtained by interviewing parents or other responsible family member. Dietary intake of subjects was assessed by
24 hours recall oral questionnaire method and their micronutrients intake was computed by using nutritive value of Indian
foods.

Result: In case of $72.8 \%, 71.2 \%, 88.2 \%$ and $6.2 \%$ subjects calcium, iron, Vitamin A and Vitamin C intakes were $<50 \%$ of Recommended Dietary Allowances. Taking 10-14 years as reference risk of less iron intake was more (AOR; $3.66 \mathrm{Cl}$ : 1.30-10.30) in subjects aged 18-19 years. When Scheduled Caste was taken as reference category, risk of less iron intake was more in subjects from other caste category (AOR; 2.91, Cl: 1.07-7.91). In comparison to subjects having sibling $\leq 4$ risk of less calcium intake was more (AOR; $4.37 \mathrm{Cl}: 1.10-17.39$ ) in subjects having sibling $>7$. With reference to vegetarians, odds of less vitamin $C$ intake was more in nonvegetarian ( $A O R=2.01$ : $\mathrm{Cl}-1.10-3.65)$ and eggitarian (AOR=2.53: $\mathrm{Cl}-1.03-6.19)$.

Conclusion: Micronutrients deficiency in urban adolescents is quiet predominant and calls for community based interventions to streamline micronutrients supplementation and therapeutic strategies.

Keywords: Dietary habit, Dietary reference intakes, Recommended dietary allowances, Socioeconomic status, Under nutrition.

\section{INTRODUCTION}

Adolescents are defined by the World Health Organization (WHO) as persons aged 10-19 years [1]. It is the period of rapid physical and psychosocial growth. During the teen years, adolescents experience changes in their physical development at a rate of speed unparalleled since infancy [2]. From third year onward the expected growth velocity (weight) is 2.25 to $2.75 \mathrm{~kg}$ per year and gain in height is 5.0 to $6.0 \mathrm{~cm}$ per year [3]. During adolescence period, $50 \%$ of adult weight, $20 \%$ of adult height and $50 \%$ adult skeletal mass are acquired [4]. Adolescent girls have the potential to gain approximately $8.3 \mathrm{~kg}$ per year during peak rates of weight gain, (12.5 years of age on average). Average weight gains during puberty among females are between $7-25 \mathrm{~kg}$, with a mean gain of 17.5 $\mathrm{kg}[5,6]$. During one-year they are likely to gain $8.89 \mathrm{~cm}$ height on an average. Besides genetic factors, nutritional intake determines the extent of growth and maturation at this stage. Poor nutrition is often cited as a major reason for the delay in the onset of puberty in

*Address correspondence to this author at the Department of Community Medicine, Institute of Medical Sciences, Banaras Hindu University, Varanasi221005, India; Tel: :+91-9451885964; E-mail: drcpmishra@gmail.com
Indian adolescents. Malnutrition has low visibility during childhood but the damage it can cause due to cumulative effect on puberty is often not appreciated. The additional requirements for iron, calcium and zinc for increments in skeletal mass, body size and bone density make 'nutrition' a critical factor in growth and development of adolescents.

In general adolescent girls are the worst sufferers of the ravages of various forms of malnutrition because of their increased nutritional need and low social power. Among modifiable factors of nutritional status dietary adequacy in terms of micronutrients is a paramount importance in general and in adolescent girls in particular. Quantity and quality of food strongly determine nutritional status of an individual which is more valid in case of adolescent girls. Any nutritional intervention for adolescent girls must give due to consideration to micronutrients intake.

In India, 22\% babies born each year have low birth weight, which has been linked to maternal undernutrition and anaemia among other causes [7] Diets of Indian adolescent girls are inadequate both in terms of quality and quantity [8]. Physical health of adolescent girls is basically determined by their nutrition. Eating 
habits and dietary behaviour picked up during adolescence have lifelong impact. Adolescence is the last chance to correct the growth lag and malnutrition [9].

Adolescent health has been a neglected area so far. Government initiatives only would not be sufficient to address their problems. Health of adolescents ultimately depends on their own actions, choices and behaviour. However, families, communities, governmental and nongovernmental organizations can not shrink from their responsibilities. Besides initiating several health and nutrition programmes empowerment of adolescents through family life and nutrition education is desired [10].

Several studies on diet surveys have shown that the diets of low income group population are inadequate when compared to recommended standards [11-14]. The common causes of malnutrition among adolescents in the poor community are less access to food and inadequate knowledge about dietary requirements [15].

According to a report of National Institute of Nutrition, in both the sexes, the proportions of adolescents consuming inadequate amounts were higher in case of micronutrients than that of protein, energy and total fat. More than two third of adolescents were consuming $<70$ per cent of RDA for vitamin $A$ and riboflavin. Extent of deficiency with respect to iron was higher in boys than in girls [16].

The consumption of sweetened dairy products was positively associated with calcium intakes for children and adolescents. Consumption of presweetened cereals increased the likelihood of the children and adolescents meeting recommendations for the essential shortfall micronutrients calcium, folate, and iron, whereas the consumption of sugar-sweetened beverages, sugars and sweets, and sweetened grains decreased the likelihood of meeting the Dietary Reference Intakes (DRI) for these nutrients. Only children who were non consumers of sugar-sweetened beverages had a mean calcium intake that met the adequate intakes. Consumption of sweetened dairy products and presweetened cereals was positively associated with the number of dairy servings consumed per day for both age groups [17].

According to a study conducted on urban adolescent girls of Bangladesh [18] compared with the national dietary intake, the cereal intake was lower but protein containing foods like pulse and nuts, meat, fish, milk and milk products were found very much near to the national intake. The intake of pulse and nut, meat, milk and milk product were $11.0 \pm 4.5,8.0 \pm 4.0,10.0$ $\pm 4.0 \mathrm{gm}$ per capita per day respectively, whereas corresponding national averages were 10.0, 6.0 and $13.0 \mathrm{gm}$ per day. On the average, $95 \%$ of calorie, 93.5 $\%$ of protein and $96.5 \%$ of fat requirement were met. For micronutrient requirement, very low intake was observed with calcium (62\%) and iron (63\%).

In a study on adolescents of Vadodara city, it was seen that nutrient intake of the adolescent children was grossly inadequate in relation to energy, protein, iron and fiber which was more pronounced in the rural children than urban [19].

Mean nutrient intake of the selected government school girls was significantly lower when compared with Recommended Dietary Allowance of Indians. Nutritional inadequacy is one of the main causes of prevalence of malnutrition that can lead to higher incidence of diseases among adolescents [20].

The adolescent girls were consuming excess of energy, protein and fat but inadequate micronutrients like iron and beta-carotene [21].

With this background this study was contemplated on adolescent girls in urban Varanasi with following objectives: [A] To assess dietary inadequacy of micronutrients in urban adolescent girls [B] To pinpoint the correlates of micronutrients inadequacy in urban adolescent girls.

\section{METHODS}

\section{Setting}

This study was conducted in urban areas of Varanasi district having a population of 1599260 which is $43.43 \%$ of total population of Varanasi (3682194). Gender ratio of the district was 909 (Rural: 926; Urban: 887). Overall literacy rate was $77.08 \%$ : corresponding value for male and female subjects was $85.12 \%$ and $68.2 \%$, respectively [22].

\section{Study Design}

A community based cross sectional design was adopted for this study.

\section{Study Sample}

Adolescent girls age group 10-19 years were considered for this study. This group was selected on 
the consideration that adolescents in general and girls in particular are vulnerable because of variety of reasons [23] and least priority was accorded in planning and execution of nutrition services for adolescent girls. Even there is paucity of data on intake of micronutrients in this age group.

\section{Sample Size}

Sample size estimation for this study was based on the consideration of prevalence of under nutrition in adolescent girls to the extent of 60 percent and permissible level of error as 10 percent. This worked out to be 256. Taking design effect of 1.5 the required sample size became 384 . Thus the total sample size was fixed to 400 .

\section{Inclusion Criteria}

All subjects with assent of subjects and consent of parents were considered as study subjects.

\section{Exclusion Criteria}

Subjects not available even after 3 visits were excluded from this study.

\section{Sampling Methodology}

Selection of sample was done adopting multistage sampling as given below:

\section{Step 1}

Varanasi city comprises of five zones (Kotwali, Dashaswamedh, Bhelupur, Adampur and Varunapar). Out of these zones of Varanasi city, two zones (Bhelupur and Varunapar) were selected by simple random sampling teqenique.

\section{Step 2}

In the second stage, in each selected zone one ward was selected by the same procedure.

\section{Step 3}

In each selected ward two mohallas were selected by simple random procedure. The selected mohallas were Sunderpur, Naria, Teliabag and Englisialine, respectively.

\section{Step 4}

In the selected mohallas household were selected according to their probability proportion to size adopting simple random sampling. In a household with more than one family, a family was selected by random technique. From each selected family one adolescent girl was selected. If a family had more than one adolescent girl, Lottery Method was used to select one of them. In case of non availability of adolescent girl in the selected family a nearby family having adolescent girl was taken.

\section{Tools of Study}

Predesigned and pretested proforma was used for this study. Information pertaining to socio -demographic and personal characteristics was recorded on this proforma. This comprised of following sections:

\section{(A) Family Schedule}

Included information pertaining to religion, caste, area of residence, type of family, total members in the family, number of adolescent girls and boys in the family, family income etc.

\section{(B) Information Regarding Socio Economic Status}

The major information given in this section for computing Socio Economic Status were per capita income, maximum education in the family, housing, family amenities, and consumption pattern of various items.

\section{(C) Individual Interview Schedule}

Included information pertaining to name, age, marital status, age at marriage of adolescent girl, literacy status and occupation of subject, father, mother and husband, number of siblings, personal history regarding menstruation.

\section{(D) Information Regarding Dietary Assessment}

a) Dietary Assessment through "24 Hour Dietary Recall Method"

Questionnaire contained different columns to note dietary intake during last 24 hours.

\section{b) Dietary Practices}

This section contained information regarding nature of diet, timing of meal, frequency of meal.

\section{Techniques of Study}

This study had approval of the Academic Bodies of Banaras Hindu University. Prior assent of study subjects and consent of her parents was taken before interviewing them. Socio-demographic information of study subjects was assessed by Interview technique. Measurement of Socio Economic Status was done through composite indicator [24] Weight for different 
variables and sub variables were assigned for each item and maximum cut of levels (weight) for different categories. The following five broad categories of social and economic proxy variables were considered for the computation of SES of a family:

(i) Monthly per capita income.

(ii) Maximum education in the family.

(iii) Type of house including number of rooms in the house.

(iv) Family amenities and possession of prestigious durable goods.

(v) Use/consumption pattern of various items.

Data for total family income was calculated by interviewing head or any responsible member of the family. If family had more than one income source, all sources were pooled together to get total family income. Separate procedures were adopted to estimate activities and the income from the other sources.
Dietary intake of study subjects was assessed by 24 Hours Dietary Recall Method. Micronutrients intake was estimated by using Nutritive value of Indian Foods [25]. and their adequacy was assessed with respect to Recommended Dietary Allowances (RDA). Information about nature of diet, frequency of meal and timing of meal was also elicited by interviewing them using predesigned and pretested proforma.

\section{Analysis of Data}

Data thus generated were analyzed with the help of Microsoft excel 2007 and SPSS version $16^{\text {th }}$ software. Appropriate tables were generated. Statistical tests $X^{2}$, and logistic regression were applied; $\mathrm{AOR}$ and $\mathrm{Cl}$ were computed for inference.

\section{RESULTS}

Average daily consumption of calcium was $41.75 \%$ of estimated RDA. Mean (mg/day) iron intake of study subjects was $11.04 \pm 5.19$; this was $44.16 \%$ of estimated RDA. Vitamin A and C intake were $25.52 \%$ and $89.8 \%$ of respective RDAs (Table 1 and Figure $\mathbf{1}$ ).

Table 1: Average Micronutrient Intake of Study Subjects

\begin{tabular}{|c|c|c|c|}
\hline Nutrient & $\begin{array}{c}\text { Nutrient intake } \\
\text { Mean } \pm \text { SD }\end{array}$ & Estimated RDA & of RDA \\
\hline \hline Calcium (mg/day) & $334.05 \pm 180.30$ & 800 & 41.75 \\
\hline Iron (mg/day) & $11.04 \pm 5.19$ & 25.13 & 44.16 \\
\hline Vitamin A ( $\mu$ g/day) & $1225 \pm 1162.8$ & 4800 & 25.52 \\
\hline Vitamin C (mg/day) & $35.92 \pm 10.58$ & 40 & 89.80 \\
\hline
\end{tabular}

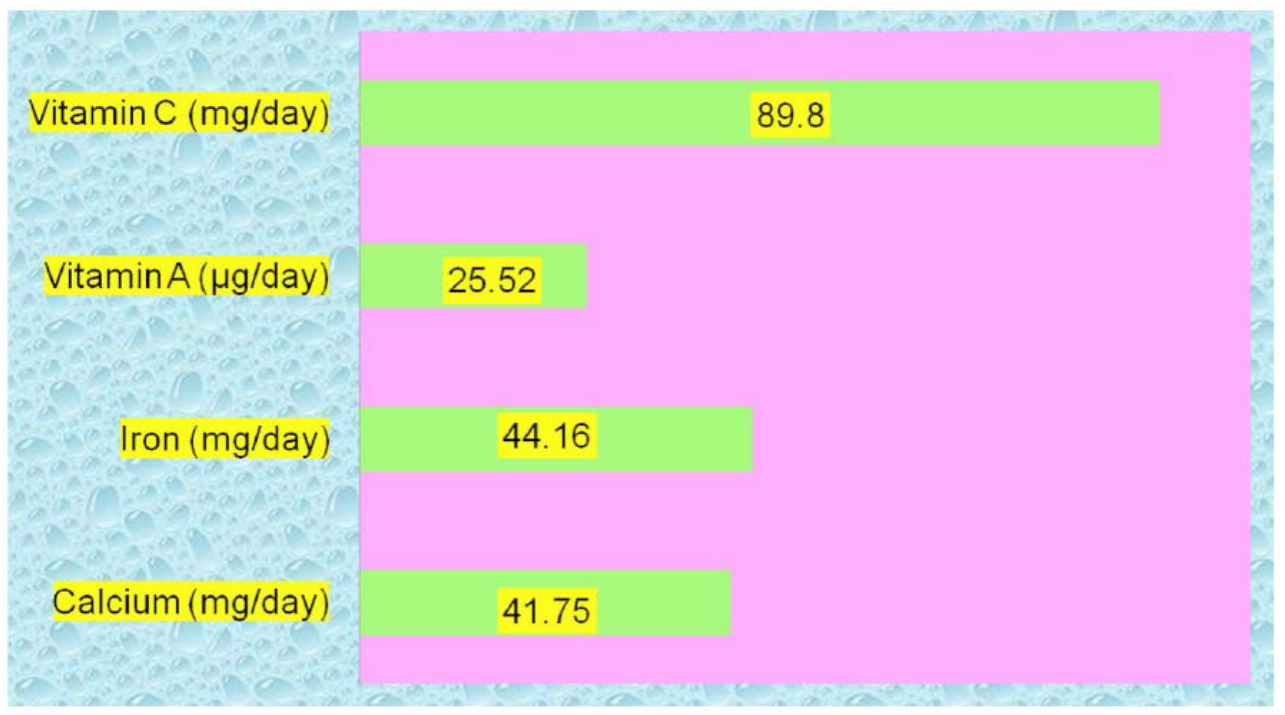

Figure 1: Average micronutrients intake of study subjects as percentage of RDA. 
Table 2: Age Wise Calcium Intake of Study Subjects

\begin{tabular}{|c|c|c|c|c|c|}
\hline Age group(years) & $\mathbf{N}$ & Mean intake (mg/day) & RDA & $\begin{array}{c}\text { Percentage } \\
\text { intake }\end{array}$ & Range \\
\hline \hline $10-12$ & 94 & $289.64 \pm 186.59$ & 800 & 36.20 & $68.8-900$ \\
\hline $13-15$ & 104 & $308.99 \pm 153.06$ & 800 & 38.62 & $65-873.4$ \\
\hline $16-17$ & 93 & $352.44 \pm 182.88$ & 800 & 44.05 & $97.1-886.2$ \\
\hline $18-19$ & 109 & $380.56 \pm 185.72$ & 800 & 47.50 & $75.7-889.68$ \\
\hline Overall & 400 & $334.05 \pm 180.30$ & 800 & 41.75 & $65-900$ \\
\hline
\end{tabular}

Average calcium intake was $289.64 \pm 186.59$, $308.99_{ \pm}+153.06, \quad 352.44 \pm 182.88$ and $380.56 \pm 185.72$ $\mathrm{mg} /$ day in $10.12,13-15,16-17$ and $18-19$ years age groups, respectively. In all age groups percentage intake of calcium was $<50 \%$ of the RDA (Table 2 ).

Age wise iron intake of study subjects is given in Table 3. Mean iron intake of adolescent girls belonging to $18-19$ years was $12.04 \pm 4.94$ which was $57.33 \%$ of RDA value. Mean intake of iron as percentage of RDA was $36.70 \%$ in $10-12$ years, $38.51 \%$ in $13-15$ years and $45.11 \%$ in $16-17$ years.

Vitamin $A$ is an important nutrient required for optimum growth, integrity of mucus membrane and skin as well as vision. There existed wide variation in consumption of substances rich in vitamin $A$ by adolescent girls. Average intake of vitamin A was least $(1155 \pm 921.5 \mathrm{mg} /$ day $)$ in the age group $10-12$ years and maximum $(1166 \pm 1306.4)$ in the age group 18-19 years. In all age groups vitamin $A$ intake as percentage of RDA was less than $30 \%$ (Table 4 ).

Vitamin C plays a significant role in skeletal growth and for maintenance of healthy gums etc. Average intake of vitamin $C$ in different age groups was compared with RDA and results are given in Table $\mathbf{5}$. Average vitamin $C$ intake was least $(33.23 \pm 10.92)$ in the age group 13-15 years age group and maximum $\left(37.49_{ \pm} 10.69\right)$ in $16-17$ years age group. Vitamin $C$ intake was more than $80.0 \%$ in all age groups.

In order to have an insight in the level of consumption of different micronutrients, intake by adolescent girls were expressed as percentage of RDA and the same is given in Table 6 . As much as $72.8 \%$, $71.2 \%, 88.2 \%$ and $6.2 \%$ subjects had calcium, iron, vitamin $A$ and vitamin $C$ intake $\leq 50 \%$ of $R D A$, respectively. In case of $7 \%, 9.5 \%, 7.2 \%$ and $64.85 \%$

Table 3: Age Wise Iron Intake of Study Subjects

\begin{tabular}{|c|c|c|c|c|c|}
\hline Age group(years) & $\mathbf{N}$ & Mean intake (mg/day) & RDA & $\begin{array}{c}\text { Percentage } \\
\text { intake }\end{array}$ & Range \\
\hline \hline $10-12$ & 94 & $9.91 \pm 5.33$ & 27 & 36.70 & $2.86-27.55$ \\
\hline $13-15$ & 104 & $10.40 \pm 4.96$ & 27 & 38.51 & $2.90-28.09$ \\
\hline $16-17$ & 93 & $11.73 \pm 5.36$ & 26 & 45.11 & $2.90-29.11$ \\
\hline $18-19$ & 109 & $12.04 \pm 4.94$ & 21 & 57.33 & $2.77-24.34$ \\
\hline Overall & 400 & $11.04 \pm 5.19$ & 25.13 & 44.16 & $2.77-29.11$ \\
\hline
\end{tabular}

Table 4: Age Wise Vitamin A intake of Study Subjects

\begin{tabular}{|c|c|c|c|c|c|}
\hline Age group(years) & $\mathbf{N}$ & Mean intake (ug/day) & RDA & Percentage intake & Range \\
\hline \hline $10-12$ & 94 & $1155 \pm 921.5$ & 4800 & 24.06 & $177.03-4900.2$ \\
\hline $13-15$ & 104 & $1230 \pm 1054.4$ & 4800 & 25.62 & $153.35-5118.15$ \\
\hline $16-17$ & 93 & $1359 \pm 1315.5$ & 4800 & 28.31 & $201.8-4919.74$ \\
\hline $18-19$ & 109 & $1166 \pm 1306.4$ & 4800 & 24.49 & $153.15-5208.45$ \\
\hline Overall & 400 & $1225 \pm 1162.8$ & 4800 & 25.52 & $153.15-5208.45$ \\
\hline
\end{tabular}


Table 5: Age Wise Vitamin C Intake of Study Subjects

\begin{tabular}{|c|c|c|c|c|c|}
\hline Age group(years) & N & Mean intake (mg/day) & RDA & Percentage intake & Range \\
\hline \hline $10-12$ & 94 & $35.56 \pm 9.75$ & 40 & 88.87 & $11.5-57.7$ \\
\hline $13-15$ & 104 & $33.23 \pm 10.92$ & 40 & 83.07 & $10.5-63.5$ \\
\hline $16-17$ & 93 & $37.49 \pm 10.69$ & 40 & 93.70 & $10-60.7$ \\
\hline $18-19$ & 109 & $37.47 \pm 10.42$ & 40 & 93.67 & $10.9-65$ \\
\hline Overall & 400 & $35.92 \pm 10.58$ & 40 & 89.8 & $10-65$ \\
\hline
\end{tabular}

Table 6: Micronutrients Intake of Adolescent Girls as Percentage of Recommended Dietary Allowances (400)

\begin{tabular}{|c|c|c|c|c|c|c|c|c|}
\hline \multirow{2}{*}{$\begin{array}{l}\text { Percentage } \\
\text { intake of RDA }\end{array}$} & \multicolumn{2}{|c|}{ Calcium } & \multicolumn{2}{|c|}{ Iron } & \multicolumn{2}{|c|}{ Vitamin A } & \multicolumn{2}{|c|}{ Vitamin C } \\
\hline & No & $\%$ & No & $\%$ & No & $\%$ & No & $\%$ \\
\hline$\leq 50$ & 291 & 72.8 & 285 & 71.2 & 353 & 88.2 & 25 & 6.2 \\
\hline $50.1-60$ & 31 & 7.8 & 39 & 9.8 & 0 & 0.0 & 36 & 9.0 \\
\hline $60.1-70$ & 28 & 7.0 & 23 & 5.8 & 4 & 1.0 & 39 & 9.8 \\
\hline $70.1-80$ & 22 & 5.5 & 15 & 3.8 & 14 & 3.5 & 41 & 10.2 \\
\hline $80.1-90$ & 10 & 2.5 & 17 & 4.2 & 10 & 2.5 & 46 & 11.5 \\
\hline $90.1-100$ & 7 & 1.8 & 6 & 1.5 & 10 & 2.5 & 56 & 14.0 \\
\hline$>100$ & 11 & 2.8 & 15 & 3.8 & 9 & 2.2 & 157 & 39.2 \\
\hline
\end{tabular}

subjects calcium, Iron, vitamin A and vitamin C intake was more than $80 \%$ of RDA, respectively.

In case of $78.2 \%$ subjects belonging to age group $10-14$ years calcium consumption was $<50 \%$ of the RDA; corresponding value for subjects in the age group $15-17$ years and $18-19$ years were $74.6 \%$ and $59.6 \%$, respectively (Table 7). Calcium consumption as percentage of RDA differed significantly $(p<0.05)$ in different age groups. There existed significant $(p<0.01)$ association between calcium consumption and caste of the study subjects. As much as $85.9 \%$ SC, $75.5 \%$ OBC and $64.1 \%$ other caste category subjects had calcium consumption $<50$ percent of RDA. As much as $78.9 \%$ primary, $79.2 \%$ middle, $76.5 \%$ high school, $68.8 \%$ intermediate and $46.9 \%$ subjects undergoing graduation had calcium consumption <50percent of RDA. There existed no significant $(p>0.05)$ association between religion, type and size of family, number of siblings, menstrual status of study subjects, total income of family, per capita income, socio economic status, literacy status and occupation of parents. Calcium consumption of study subjects expressed as percentage of RDA did not differ significantly ( $p>0.05$ ) in vegetarian, nonvegetarian and eggetarian subjects. As much as $83.9 \%, 70.3 \%$ and $72.7 \%$ subjects having frequency of meal twice, thrice, four times a day, respectively, had calcium consumption $<50 \%$ of the
RDA ( $p>0.05$ ). In case of $72.2 \%$ subjects having fixed timings of meal calcium consumption was $<50$ percent of RDA; corresponding value for subjects with irregular time of meal $71.7 \%(p>0.05)$.

In comparison to subjects having sibling $\leq 4$ risk of less calcium intake was more (AOR 4.37 ; $\mathrm{Cl}$ : 1.1017.39 ) in subjects having sibling $>7$. Effect of significant association of age, caste, subjects literacy on less calcium intake in univariate analysis got eliminated in logistic model (Table 8). The appropriateness of the model for correct prediction of calcium intake was $78.8 \%$ which is acceptable.

In case of $82.4 \%, 73.8 \%$ and $50.0 \%$ subjects belonging to age group $10-14,15-17$ and $18-19$ years iron consumption was $<50 \%$ of the $\operatorname{RDA}(p<0.01)$. As much as $68.0 \%$ subjects from nuclear family and $76.4 \%$ subjects from joint family had iron consumption $<50$ percent of RDA. Iron consumption was significantly $(p<0.01)$ more in menstruating than nonmenstruating girls; $32.8 \%$ menstruating and $13 \%$ nonmenstruating girls had iron consumption $\geq 50$ percent of RDA. Iron consumption as percentage of RDA was also significantly associated with literacy status of subjects and nature of diet (Table 9).

In comparison to age group 10-14 years risk of less iron intake was more (AOR; $3.64 ; \mathrm{Cl}: 1.30-10.30)$ in 
Table 7: Calcium Consumption of Adolescent Girls According to their Sociodemographic and Personal Characteristics

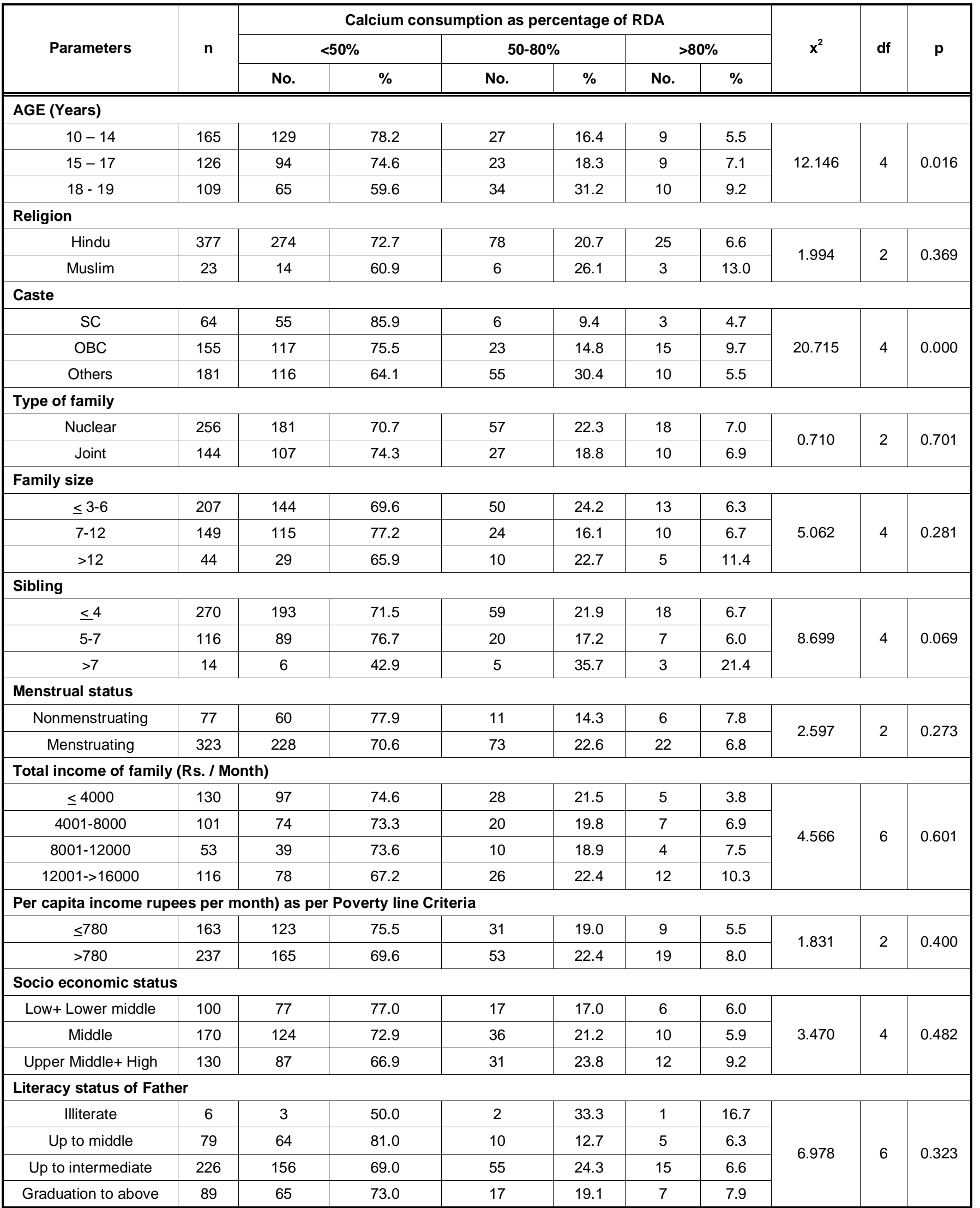


(Table 7). Continued.

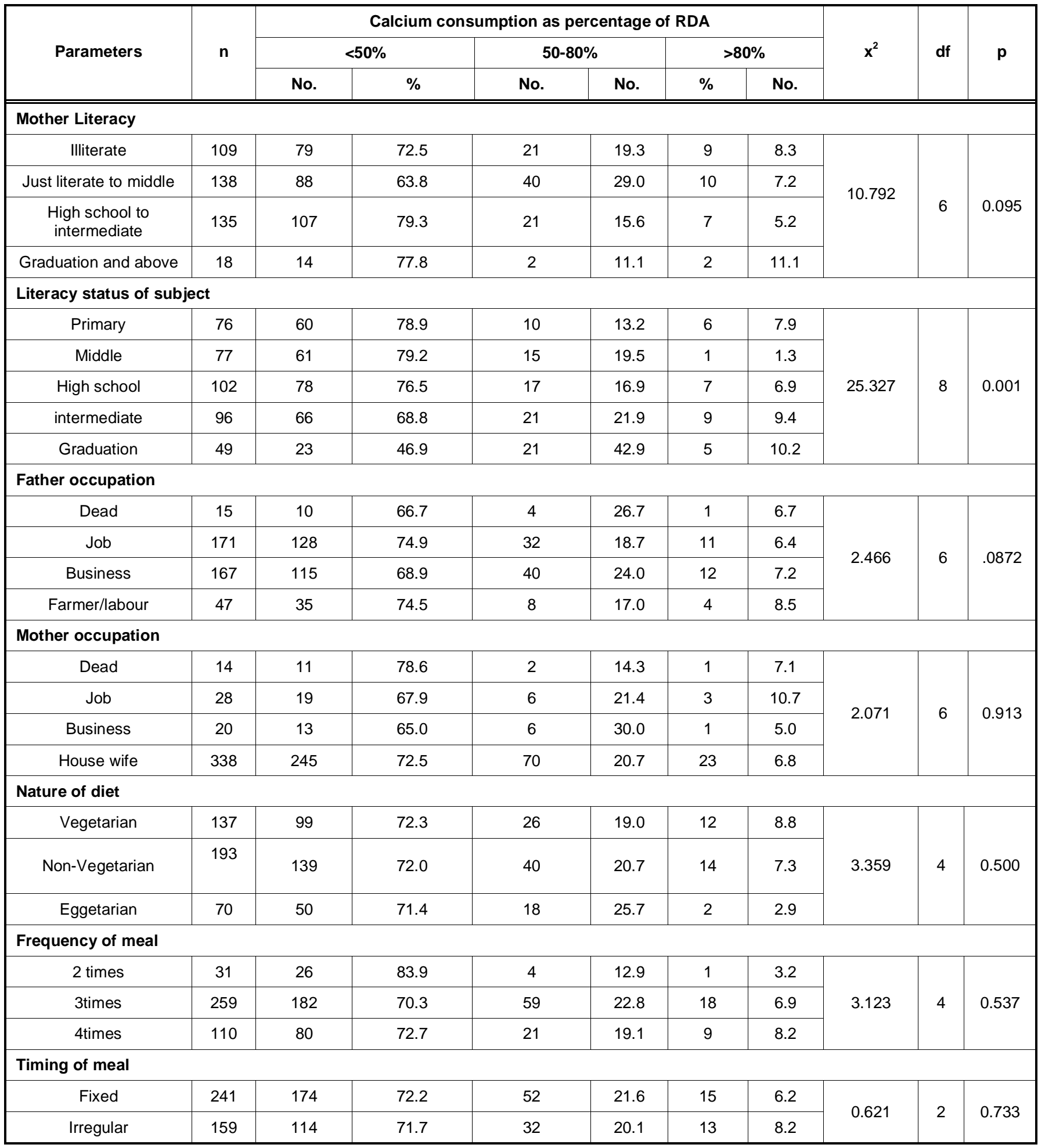

subjects aged 18-19 years. Taking SC as reference category risk of less iron intake was more in subjects from other caste category (AOR; 2.91,Cl: 1.07-7.91). The appropriateness of the model for correct prediction of iron intake was $81.0 \%$ which is acceptable (Table 10).
Vitamin A consumption of adolescent girls according to their socio demographic and personal characteristics is given in Table 11. In case of 18-19 years subjects vitamin $A$ consumption as percentage of RDA was $>80 \%$ in $11.0 \%$ subjects; corresponding value for $10-14$ and $15-17$ years were $5.5 \%$ and $6.3 \%$, 
Table 8: Result of Logistic Regression Analysis (Calcium Intake Status Verses Socio-Demographic Characteristics)

\begin{tabular}{|c|c|c|c|c|c|c|}
\hline Particulars & variables & $\begin{array}{c}\text { Percentage of } \\
\text { observations }\end{array}$ & Beta & p-value & AOR & 95.0\% C.I. \\
\hline \hline \multirow{3}{*}{ Age (years) } & $10-14$ & 40.2 & - & - & - & - \\
\cline { 2 - 7 } & $15-17$ & 31.5 & 0.30 & 0.49 & 1.35 & $0.57-3.22$ \\
\cline { 2 - 7 } & $18-19$ & 27.2 & 0.47 & 0.34 & 1.60 & $0.60-4.28$ \\
\hline \multirow{4}{*}{ Caste } & SC & 16.0 & - & - & - & - \\
\cline { 2 - 7 } & OBC & 38.7 & 0.54 & 0.27 & 1.72 & $0.65-4.54$ \\
\cline { 2 - 7 } & Others & 45.3 & 0.74 & 0.12 & 2.10 & $0.81-5.44$ \\
\hline \multirow{4}{*}{ Subject Literacy } & Primary & 19.0 & - & - & - & - \\
\cline { 2 - 7 } & Middle & 19.2 & 0.01 & 0.98 & 0.97 & $0.36-2.71$ \\
\cline { 2 - 7 } & High school & 25.5 & 0.25 & 0.66 & 1.29 & $0.42-3.92$ \\
\cline { 2 - 7 } & Intermediate & 24.0 & 0.58 & 0.32 & 1.79 & $0.57-5.62$ \\
\hline \multirow{3}{*}{ Sibling } & Graduation & 12.0 & 0.82 & 0.23 & 2.26 & $0.59-8.67$ \\
\cline { 2 - 7 } & $\leq 4$ & 67.5 & & 0.06 & & \\
\cline { 2 - 7 } & $5-7$ & 29.0 & 0.25 & 0.45 & 0.77 & $0.40-1.50$ \\
\hline
\end{tabular}

Table 9: Iron Consumption of Adolescent Girls According to their Sociodemographic and Personal Characteristics

\begin{tabular}{|c|c|c|c|c|c|c|c|c|c|c|}
\hline \multirow{3}{*}{ Parameters } & \multirow{3}{*}{$\mathbf{n}$} & \multicolumn{6}{|c|}{ Iron consumption as percentage of RDA } & \multirow{3}{*}{$x^{2}$} & \multirow{3}{*}{ df } & \multirow{3}{*}{$\mathbf{p}$} \\
\hline & & \multicolumn{2}{|c|}{$<50 \%$} & \multicolumn{2}{|c|}{$50-80 \%$} & \multicolumn{2}{|c|}{$>80 \%$} & & & \\
\hline & & No. & $\%$ & No. & $\%$ & No. & $\%$ & & & \\
\hline \multicolumn{11}{|l|}{ AGE (Years) } \\
\hline $10-14$ & 165 & 136 & 82.4 & 20 & 12.1 & 9 & 5.5 & \multirow{3}{*}{35.858} & \multirow{3}{*}{4} & \multirow{3}{*}{0.000} \\
\hline $15-17$ & 126 & 93 & 73.8 & 25 & 19.8 & 8 & 6.3 & & & \\
\hline $18-19$ & 109 & 55 & 50.0 & 33 & 30.3 & 21 & 19.3 & & & \\
\hline \multicolumn{11}{|l|}{ Religion } \\
\hline Hindu & 377 & 267 & 70.8 & 73 & 19.4 & 37 & 9.8 & \multirow{2}{*}{0.774} & \multirow{2}{*}{2} & \multirow{2}{*}{0.679} \\
\hline Muslim & 23 & 17 & 73.9 & 5 & 21.7 & 1 & 4.3 & & & \\
\hline \multicolumn{11}{|l|}{ Caste } \\
\hline SC & 64 & 50 & 78.1 & 10 & 15.6 & 4 & 6.2 & \multirow{3}{*}{5.047} & \multirow{3}{*}{4} & \multirow{3}{*}{0.283} \\
\hline OBC & 155 & 112 & 72.3 & 32 & 20.6 & 11 & 7.1 & & & \\
\hline Others & 181 & 122 & 67.4 & 36 & 19.9 & 23 & 12.7 & & & \\
\hline \multicolumn{11}{|l|}{ Type of family } \\
\hline Nuclear & 256 & 174 & 68.0 & 60 & 23.4 & 22 & 8.6 & \multirow{2}{*}{7.189} & \multirow{2}{*}{2} & \multirow{2}{*}{0.027} \\
\hline Joint & 144 & 110 & 76.4 & 18 & 12.5 & 16 & 11.1 & & & \\
\hline \multicolumn{11}{|l|}{ Family size } \\
\hline$\leq 3-6$ & 207 & 140 & 67.6 & 48 & 23.2 & 19 & 9.2 & \multirow{3}{*}{4.730} & \multirow{3}{*}{4} & \multirow{3}{*}{0.316} \\
\hline $7-12$ & 149 & 113 & 75.8 & 23 & 15.4 & 13 & 8.7 & & & \\
\hline$>12$ & 44 & 31 & 70.5 & 7 & 15.9 & 6 & 13.6 & & & \\
\hline
\end{tabular}


(Table 9). Continued.

\begin{tabular}{|c|c|c|c|c|c|c|c|c|c|c|}
\hline \multirow{3}{*}{ Parameters } & \multirow{3}{*}{$\mathbf{n}$} & \multicolumn{6}{|c|}{ Iron consumption as percentage of RDA } & \multirow{3}{*}{$\mathbf{x}^{2}$} & \multirow{3}{*}{ df } & \multirow{3}{*}{$\mathbf{p}$} \\
\hline & & \multicolumn{2}{|c|}{$<50 \%$} & \multicolumn{2}{|c|}{$50-80 \%$} & \multicolumn{2}{|c|}{$>80 \%$} & & & \\
\hline & & No. & $\%$ & No. & No. & $\%$ & No. & & & \\
\hline \multicolumn{11}{|l|}{ Sibling } \\
\hline$\leq 4$ & 270 & 185 & 68.5 & 54 & 20.0 & 31 & 11.5 & \multirow{3}{*}{5.951} & \multirow{3}{*}{4} & \multirow{3}{*}{0.203} \\
\hline $5-7$ & 116 & 90 & 77.6 & 21 & 18.1 & 5 & 4.3 & & & \\
\hline$>7$ & 14 & 9 & 64.3 & 3 & 21.4 & 2 & 14.3 & & & \\
\hline \multicolumn{11}{|l|}{ Menstrual status } \\
\hline Nonmenstruating & 77 & 67 & 87.0 & 4 & 5.2 & 6 & 7.8 & \multirow{2}{*}{13.743} & \multirow{2}{*}{2} & \multirow{2}{*}{0.001} \\
\hline Menstruating & 323 & 217 & 67.2 & 74 & 22.9 & 32 & 9.9 & & & \\
\hline \multicolumn{11}{|c|}{ Total income of family (Rs. / Month) } \\
\hline$\leq 4000$ & 130 & 99 & 76.2 & 25 & 19.2 & 6 & 4.6 & \multirow{4}{*}{8.750} & \multirow{4}{*}{6} & \multirow{4}{*}{0.188} \\
\hline $4001-8000$ & 101 & 67 & 66.3 & 20 & 19.8 & 14 & 13.9 & & & \\
\hline $8001-12000$ & 53 & 40 & 75.5 & 10 & 18.9 & 3 & 5.7 & & & \\
\hline $12001->16000$ & 116 & 78 & 67.2 & 23 & 19.8 & 15 & 12.9 & & & \\
\hline \multicolumn{11}{|c|}{ Per capita income rupees per month) as per Poverty line Criteria } \\
\hline$\leq 780$ & 163 & 124 & 76.1 & 28 & 17.2 & 11 & 6.7 & & & \\
\hline$>780$ & 237 & 160 & 67.5 & 50 & 21.1 & 27 & 11.4 & 0.001 & $<$ & 0.100 \\
\hline Socio economic statu & & & & & & & & & & \\
\hline Low + Lower middle & 100 & 79 & 79.0 & 17 & 17.0 & 4 & 4.0 & & & \\
\hline Middle & 170 & 115 & 67.6 & 36 & 21.2 & 19 & 11.2 & 6.054 & 4 & 0.195 \\
\hline Upper Middle+ High & 130 & 90 & 69.2 & 25 & 19.2 & 15 & 11.5 & & & \\
\hline Literacy status of Fatl & & & & & & & & & & \\
\hline Illiterate & 6 & 5 & 83.3 & 0 & 0.0 & 1 & 16.7 & & & \\
\hline Up to middle & 79 & 60 & 75.9 & 11 & 13.9 & 8 & 10.1 & & & \\
\hline Up to intermediate & 226 & 156 & 69.0 & 46 & 20.4 & 24 & 10.6 & & & \\
\hline Graduation to above & 89 & 63 & 70.8 & 21 & 23.6 & 5 & 5.6 & & & \\
\hline Mother Literacy & & & & & & & & & & \\
\hline Illiterate & 109 & 81 & 74.3 & 16 & 14.7 & 12 & 11.0 & & & \\
\hline Just literate to middle & 138 & 90 & 65.2 & 35 & 25.4 & 13 & 9.4 & & & \\
\hline $\begin{array}{l}\text { High school to } \\
\text { intermediate }\end{array}$ & 135 & 100 & 74.1 & 24 & 17.8 & 11 & 8.1 & 5.584 & 6 & 0.471 \\
\hline Graduation and above & 18 & 13 & 72.2 & 3 & 16.7 & 2 & 11.1 & & & \\
\hline Literacy status of sub & & & & & & & & & & \\
\hline Primary & 76 & 64 & 84.2 & 7 & 9.2 & 5 & 6.6 & & & \\
\hline Middle & 77 & 64 & 83.1 & 9 & 11.7 & 4 & 5.2 & & & \\
\hline High school & 102 & 74 & 72.5 & 21 & 20.6 & 7 & 6.9 & 37.347 & 8 & 0.000 \\
\hline intermediate & 96 & 62 & 64.6 & 23 & 24.0 & 11 & 11.5 & & & \\
\hline Graduation & 49 & 20 & 40.8 & 18 & 36.7 & 11 & 22.4 & & & \\
\hline Father occupation & & & & & & & & & & \\
\hline Dead & 15 & 11 & 73.3 & 1 & 6.7 & 3 & 20.0 & & & \\
\hline Job & 171 & 119 & 69.6 & 38 & 22.2 & 14 & 8.2 & & & 0.584 \\
\hline Business & 167 & 119 & 71.3 & 32 & 19.2 & 16 & 9.6 & טנט & 0 & \\
\hline Farmer/labour & 47 & 35 & 17.5 & 7 & 14.9 & 5 & 10.6 & & & \\
\hline
\end{tabular}


(Table 9). Continued.

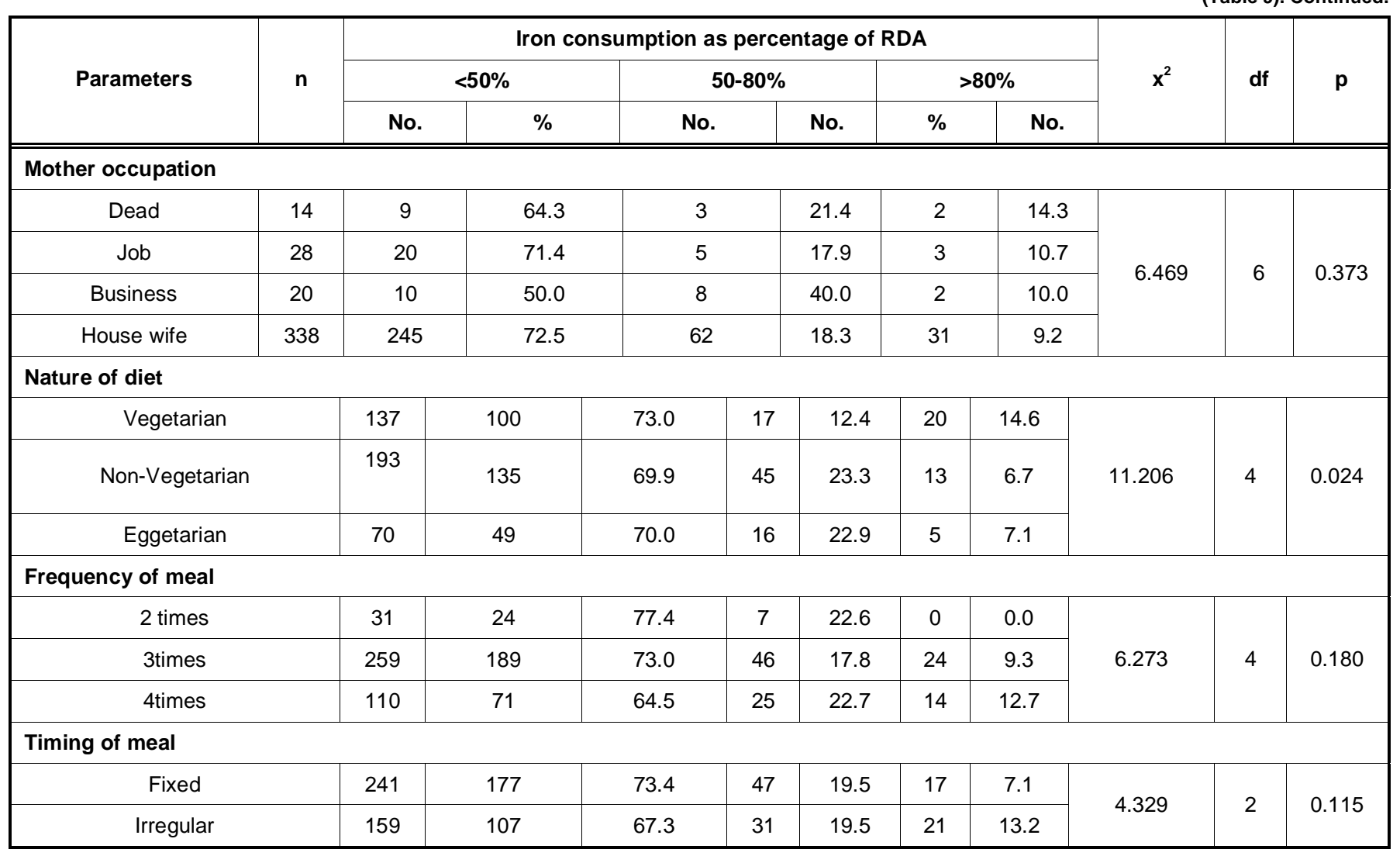

Table 10: Result of Logistic Regression Analysis (Iron Intake Status Verses Sociodemographic Characteristics)

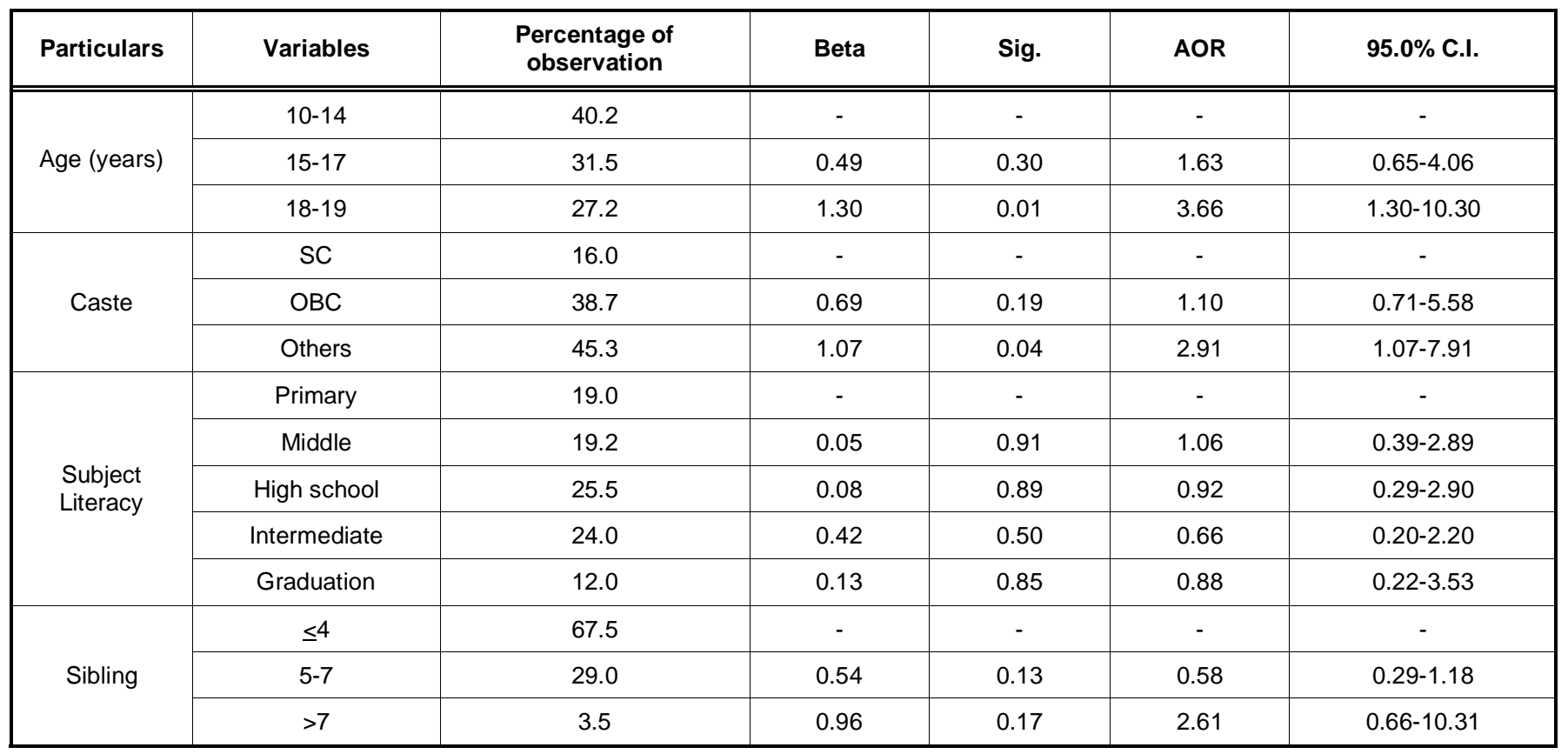

respectively. None of other socio-demographic and personal variables (viz. religion, caste, type and size of family, number of siblings, menstrual status, total income of family, per capita income, SES, literacy status of self and parents, occupation of parents, nature of diet, frequency and timing of meal) were significantly associated with vitamin A consumption expressed as percentage of RDA. 
Table 11: Vitamin A Consumption of Adolescent Girls According to their Socio Demographic and Personal Characteristics

\begin{tabular}{|c|c|c|c|c|c|c|c|c|c|c|}
\hline \multirow{3}{*}{ Parameters } & \multirow{3}{*}{$\mathbf{n}$} & \multicolumn{6}{|c|}{ Vitamin A consumption as percentage of RDA } & \multirow{3}{*}{$x^{2}$} & \multirow{3}{*}{ df } & \multirow{3}{*}{$\mathbf{p}$} \\
\hline & & \multicolumn{2}{|c|}{$<50 \%$} & \multicolumn{2}{|c|}{$50-80 \%$} & \multicolumn{2}{|c|}{$>80 \%$} & & & \\
\hline & & No. & $\%$ & No. & $\%$ & No. & $\%$ & & & \\
\hline \multicolumn{11}{|l|}{ AGE (Years) } \\
\hline $10-14$ & 165 & 151 & 91.5 & 5 & 3.0 & 9 & 5.5 & \multirow[b]{2}{*}{10.895} & \multirow[b]{2}{*}{4} & \multirow[b]{2}{*}{0.028} \\
\hline $15-17$ & 126 & 107 & 84.9 & 11 & 8.7 & 8 & 6.3 & & & \\
\hline \multicolumn{11}{|l|}{ Religion } \\
\hline Hindu & 377 & 335 & 88.9 & 16 & 4.2 & 26 & 6.9 & \multirow{2}{*}{2.360} & \multirow{2}{*}{2} & \multirow{2}{*}{0.307} \\
\hline Muslim & 23 & 18 & 78.3 & 2 & 8.7 & 3 & 13.0 & & & \\
\hline \multicolumn{11}{|l|}{ Caste } \\
\hline SC & 64 & 61 & 95.3 & 1 & 1.6 & 2 & 3.1 & 6.412 & 4 & 0.170 \\
\hline Nuclear & 256 & 221 & 86.3 & 15 & 5.9 & 20 & 7.8 & 2 500 & 2 & 0171 \\
\hline Joint & 144 & 132 & 91.7 & 3 & 2.1 & 9 & 6.2 & $0.0<0$ & 5 & I.1. \\
\hline Family size & & & & & & & & & & \\
\hline$\leq 3-6$ & 207 & 177 & 85.5 & 12 & 5.8 & 18 & 8.7 & & & \\
\hline $7-12$ & 149 & 138 & 92.6 & 5 & 3.4 & 6 & 4.0 & 5.968 & 4 & 0.202 \\
\hline$>12$ & 44 & 38 & 86.4 & 1 & 2.3 & 5 & 11.4 & & & \\
\hline Sibling & & & & & & & & & & \\
\hline$\leq 4$ & 270 & 237 & 87.8 & 13 & 4.8 & 20 & 7.4 & & & \\
\hline$\leq 4000$ & 130 & 114 & 87.7 & 7 & 5.4 & 9 & 6.9 & & & \\
\hline $4001-8000$ & 101 & 92 & 91.1 & 4 & 4.0 & 5 & 5.0 & 4748 & 6 & 0577 \\
\hline $8001-12000$ & 53 & 45 & 84.9 & 1 & 1.9 & 7 & 13.2 & 4.140 & 0 & TI \\
\hline $12001->16000$ & 116 & 102 & 87.9 & 6 & 5.2 & 8 & 6.9 & & & \\
\hline Per capita income ru & s per & th) as & erty li & & & & & & & \\
\hline$\leq 780$ & 163 & 144 & 88.3 & 7 & 4.3 & 12 & 7.4 & 0031 & 2 & 0985 \\
\hline$>780$ & 237 & 209 & 88.2 & 11 & 4.6 & 17 & 7.2 & ו וטס & 5 & 0.000 \\
\hline Socio economic stat & & & & & & & & & & \\
\hline $\begin{array}{c}\text { Low } \\
+ \text { Lower middle }\end{array}$ & 100 & 90 & 90.0 & 3 & 3.0 & 7 & 7.0 & 0 & & \\
\hline Middle & 170 & 149 & 87.6 & 9 & 5.3 & 12 & 7.1 & 0.041 & 4 & 0.900 \\
\hline Upper Middle+ High & 130 & 114 & 87.7 & 6 & 4.6 & 10 & 7.7 & & & \\
\hline Literacy status of Fat & & & & & & & & & & \\
\hline Illiterate & 6 & 5 & 83.3 & 0 & 0.0 & 1 & 16.7 & & & \\
\hline Up to middle & 79 & 70 & 88.6 & 4 & 5.1 & 5 & 6.3 & 3861 & 6 & 0696 \\
\hline Up to intermediate & 226 & 200 & 88.5 & 12 & 5.3 & 14 & 6.2 & 0.001 & 0 & 0.050 \\
\hline Graduation to above & 89 & 78 & 87.6 & 2 & 2.2 & 9 & 10.1 & & & \\
\hline
\end{tabular}


(Table 11). Continued.

\begin{tabular}{|c|c|c|c|c|c|c|c|c|c|c|}
\hline \multirow{2}{*}{ Parameters } & \multirow{2}{*}{$\mathbf{n}$} & \multicolumn{6}{|c|}{ Vitamin A consumption as percentage of RDA } & \multirow{2}{*}{$x^{2}$} & \multirow{2}{*}{ df } & \multirow{2}{*}{$\mathbf{p}$} \\
\hline & & No. & $\%$ & No. & No. & $\%$ & No. & & & \\
\hline \multicolumn{11}{|l|}{ Mother Literacy } \\
\hline Illiterate & 109 & 97 & 89.0 & 5 & 4.6 & 7 & 6.4 & \multirow{2}{*}{3.752} & \multirow{2}{*}{6} & \multirow{2}{*}{0.710} \\
\hline Graduation and above & 18 & 18 & 100.0 & 0 & 0.0 & 0 & 0.0 & & & \\
\hline \multicolumn{11}{|c|}{ Literacy status of subject } \\
\hline Primary & 76 & 71 & 93.4 & 2 & 2.6 & 3 & 3.9 & \multirow{2}{*}{7.640} & \multirow{2}{*}{8} & \multirow{2}{*}{0.469} \\
\hline Graduation & 49 & 44 & 89.8 & 1 & 2.0 & 4 & 8.2 & & & \\
\hline \multicolumn{11}{|l|}{ Father occupation } \\
\hline Dead & 15 & 14 & 93.3 & 0 & 0.0 & 1 & 6.7 & \multirow{4}{*}{2.766} & \multirow{4}{*}{6} & \multirow{4}{*}{0.838} \\
\hline Job & 171 & 153 & 89.5 & 6 & 3.5 & 12 & 7.0 & & & \\
\hline Business & 167 & 144 & 86.2 & 9 & 5.4 & 14 & 8.4 & & & \\
\hline Farmer/labour & 47 & 42 & 89.4 & 3 & 6.4 & 2 & 4.3 & & & \\
\hline \multicolumn{11}{|l|}{ Mother occupation } \\
\hline Dead & 14 & 12 & 85.7 & 2 & 14.3 & 0 & 0.0 & 9.654 & 6 & 0.140 \\
\hline Non-Vegetarian & 193 & 170 & 88.1 & 10 & 5.2 & 13 & 6.7 & 2.051 & 4 & 0.726 \\
\hline Eggetarian & 70 & 63 & 90.0 & 1 & 1.4 & 6 & 8.6 & & & \\
\hline Frequency of meal & & & & & & & & & & \\
\hline 2 times & 31 & 28 & 90.3 & 3 & 9.7 & 0 & 0.0 & & & \\
\hline 3times & 259 & 227 & 87.6 & 10 & 3.9 & 22 & 8.5 & 5.037 & 4 & 0.284 \\
\hline 4times & 110 & 98 & 89.1 & 5 & 4.5 & 7 & 6.4 & & & \\
\hline Timing of meal & & & & & & & & & & \\
\hline Fixed & 241 & 207 & 85.9 & 12 & 5.0 & 22 & 9.1 & 3643 & 2 & 0162 \\
\hline Irregular & 159 & 146 & 91.8 & 6 & 3.8 & 7 & 4.4 & 0.070 & 2 & \\
\hline
\end{tabular}

Vitamin C consumption of study subjects as percentage of RDA was not significantly associated with their age, religion, caste, type and size of family, number of siblings, menstrual status, literacy status of self and parents, father's occupation, nature of diet, frequency and timing of meal. Vitamin $C$ intake of adolescent girls having mother's occupation as house wife was $>80 \%$ of RDA in $65.7 \%$; corresponding value for subjects with mother's occupation as job and business were $53.6 \%$ and $75.0 \%$, respectively $(p<0.05)$ (Table 12). 
Table 12: Vitamin C Consumption of Adolescent Girls According to their Socio Demographic and Personal Characteristics

\begin{tabular}{|c|c|c|c|c|c|c|c|c|c|c|}
\hline \multirow{3}{*}{ Parameters } & \multirow{3}{*}{$\mathbf{n}$} & \multicolumn{6}{|c|}{ Vitamin $\mathrm{C}$ consumption as percentage of RDA } & \multirow{3}{*}{$x^{2}$} & \multirow{3}{*}{ df } & \multirow{3}{*}{$\mathbf{p}$} \\
\hline & & \multicolumn{2}{|c|}{$<50 \%$} & \multicolumn{2}{|c|}{$50-80 \%$} & \multicolumn{2}{|c|}{$>80 \%$} & & & \\
\hline & & No. & $\%$ & No. & $\%$ & No. & $\%$ & & & \\
\hline \multicolumn{11}{|l|}{ AGE (Years) } \\
\hline $10-14$ & 165 & 14 & 8.5 & 47 & 28.5 & 104 & 63.0 & \multirow[b]{2}{*}{3.793} & \multirow[b]{2}{*}{4} & \multirow[b]{2}{*}{0.435} \\
\hline $15-17$ & 126 & 6 & 4.8 & 41 & 32.5 & 79 & 62.7 & & & \\
\hline \multicolumn{11}{|l|}{ Religion } \\
\hline Hindu & 377 & 24 & 6.4 & 106 & 28.1 & 247 & 65.5 & \multirow{2}{*}{2.501} & \multirow{2}{*}{2} & \multirow{2}{*}{0.286} \\
\hline Muslim & 23 & 1 & 4.3 & 10 & 43.5 & 12 & 52.2 & & & \\
\hline \multicolumn{11}{|l|}{ Caste } \\
\hline SC & 64 & 6 & 9.4 & 20 & 31.2 & 38 & 59.4 & 1.866 & 4 & 0.760 \\
\hline Nuclear & 256 & 17 & 6.6 & 71 & 27.7 & 168 & 65.6 & 0650 & 0 & ר?7 0 \\
\hline Joint & 144 & 8 & 5.6 & 45 & 31.2 & 91 & 63.2 & 0.050 & 2 & $0.1<2$ \\
\hline Family size & & & & & & & & & & \\
\hline$\leq 3-6$ & 207 & 15 & 7.2 & 54 & 26.1 & 138 & 66.7 & & & \\
\hline $7-12$ & 149 & 9 & 6.0 & 44 & 29.5 & 96 & 64.4 & 4.772 & 4 & 0.311 \\
\hline$>12$ & 44 & 1 & 2.3 & 18 & 40.9 & 25 & 56.8 & & & \\
\hline Sibling & & & & & & & & & & \\
\hline$\leq 4$ & 270 & 17 & 6.3 & 69 & 25.6 & 184 & 68.1 & & & \\
\hline$\leq 4000$ & 130 & 10 & 7.7 & 43 & 33.1 & 77 & 59.2 & & & \\
\hline $4001-8000$ & 101 & 10 & 9.9 & 28 & 27.7 & 63 & 62.4 & 12812 & 6 & 0016 \\
\hline $8001-12000$ & 53 & 1 & 1.9 & 20 & 37.7 & 32 & 60.4 & 12.012 & 0 & 0.040 \\
\hline $12001->16000$ & 116 & 4 & 3.4 & 25 & 21.6 & 87 & 75.0 & & & \\
\hline Per capita income ru & s per & th) as & verty I & & & & & & & \\
\hline$\leq 780$ & 163 & 12 & 7.4 & 57 & 35.0 & 94 & 57.7 & 6055 & 0 & 0018 \\
\hline$>780$ & 237 & 13 & 5.5 & 59 & 24.9 & 165 & 69.6 & 0.050 & 2 & 0.040 \\
\hline Socio economic stat & & & & & & & & & & \\
\hline Low+ Lower middle & 100 & 4 & 4.0 & 38 & 38.0 & 58 & 58.0 & & & \\
\hline Middle & 170 & 17 & 10.0 & 47 & 27.6 & 106 & 62.4 & 13.067 & 4 & 0.011 \\
\hline Upper Middle+ High & 130 & 4 & 3.1 & 31 & 23.8 & 95 & 73.1 & & & \\
\hline Literacy status of Fat & & & & & & & & & & \\
\hline Illiterate & 6 & 1 & 16.7 & 1 & 16.7 & 4 & 66.7 & & & \\
\hline Up to middle & 79 & 5 & 6.3 & 18 & 22.8 & 56 & 70.9 & 7328 & 6 & 0292 \\
\hline Up to intermediate & 226 & 17 & 7.5 & 72 & 31.9 & 137 & 60.0 & $1.0<0$ & 0 & $0 .<v e$ \\
\hline Graduation to above & 89 & 2 & 2.2 & 25 & 28.1 & 62 & 69.7 & & & \\
\hline
\end{tabular}


(Table 12). Continued

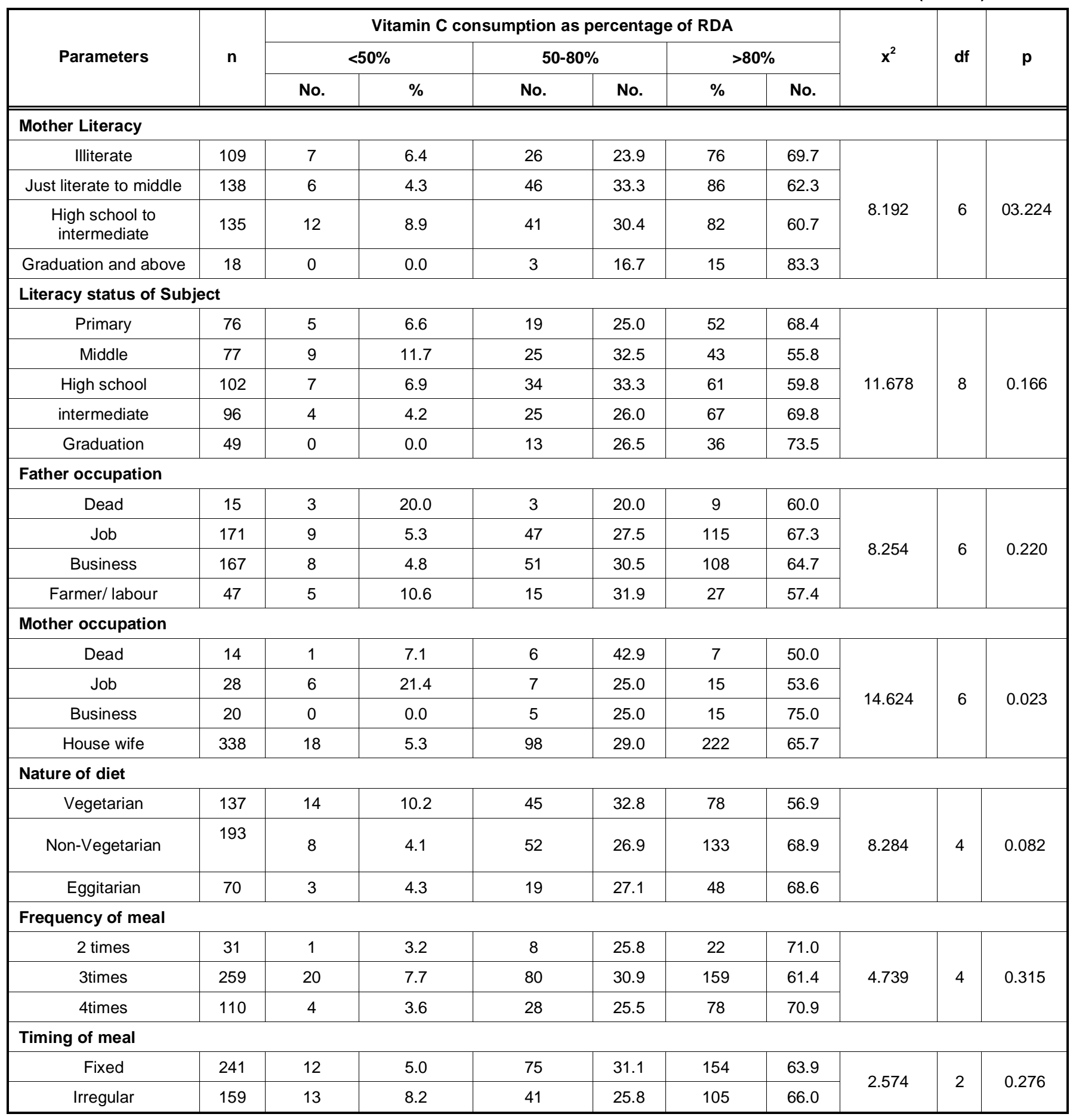

Taking subjects without mother as reference odds of less vitamin C intake was less (AOR 0.09; Cl:0.01$0.92)$ in subjects whose mother were engaged in job. In comparison to vegetarians, odds of less vitamin $\mathrm{C}$ intake was more in nonvegetarian (AOR 2.01 ; Cl: 1.103.65) and eggitarian (AOR 2.53; Cl:1.03-6.19). The appropriateness of the logistic model for correct prediction of vitamin C intake was $84.8 \%$ which is acceptable (Table 13).

\section{DISCUSSION}

In the post independent era of the planning process India primarily concentrated on maternal and child health. However, recently the focus is shifted on adolescents in general and girls in particular. By sheer number adolescents account for one fifth in the population. Seventy percent of the deaths in adulthood is linked to habits picked up during adolescence. Due 
Table 13: Result of Logistic Regression Analysis (Risk of Less Vitamin C Intake Status Verses Sociodemographic Characteristics)

\begin{tabular}{|c|c|c|c|c|c|c|}
\hline \multirow{2}{*}{ Particulars } & Variables & $\begin{array}{c}\text { Percentage of } \\
\text { observations }\end{array}$ & Beta & Sig. & AOR & 95.0\% C.I. \\
\hline \hline \multirow{3}{*}{ Mother occupation } & Dead & 3.5 & - & - & - & - \\
\cline { 2 - 7 } & Job & 7.0 & -2.39 & 0.04 & 0.09 & $0.01-0.92$ \\
\cline { 2 - 7 } & Business & 5.0 & -1.23 & 0.24 & 0.29 & $0.04-2.26$ \\
\cline { 2 - 7 } & House wife & 84.5 & -2.15 & 0.05 & 0.12 & $0.01-1.04$ \\
\hline \multirow{3}{*}{ Nature of diet } & Vegetarian & 34.3 & - & - & - & 2.01 \\
\cline { 2 - 7 } & Non- Vegetarian & 48.2 & 0.93 & 0.04 & 2.53 & $1.10-3.65$ \\
\cline { 2 - 7 } & Eggetarian & 17.5 & $0.02-6.19$ \\
\hline
\end{tabular}

to the impact of urbanization and globalization the indigenous dietary practices are changing very fast and fast food culture is a potential threat in adolescents. Adolescents are sufferers of macronutrients deficiency [26]. However for their optimum health micronutrients adequacy is of paramount importance. This study amply highlighted that adolescent girls are more victims of micronutrients inadequacy. In conformity with the findings of present study micronutrients deficiency in the urban adolescent girls have been reported in several studies. In conformity with the findings of Bidad et al [27] calcium intake has been less in urban adolescent girls of Varanasi. Vitamin A and $C$ intakes have been below RDA in adolescents factory workers [28]. In the present study average vitamin A consumption has been alarmingly low whereas this was not the case for vitamin $\mathrm{C}$. According to a report [16] more than two third adolescent girls consumed Vitamin A less than $70 \%$ of RDA. Ascorbic acid adequacy was also reported in a study conducted in Bangladesh. However both present as well as another study [29] reported average intake of iron less than $50 \%$ of RDA. Bangladesh study reported that mean daily iron intake was observed to be less than 50 per cent of the RDA, whereas the ascorbic acid intake was adequate, leading to many adolescent girls having normal haemoglobin levels inspite of iron consumption being less than RDA.

A study on adolescent female factory workers in urban Bangladesh food intake data revealed a mean intake of calcium, iron, vitamin A, thiamin, riboflavin, niacin and vitamin $\mathrm{C}$ were below the RDA. Most of the energy and nutrients came from cereal and grains [27].

In a study the micronutrient intake of students, subjects were divided into 2 groups of 11-13 and 14$18 \mathrm{yr}$ of age (to properly compare the intakes with the DRIs). In the first group (11-13 yr), students had mean intakes lower for folic acid, vitamin E, calcium, magnesium, phosphorus, potassium and sodium. In the second group (14-18 yr), students had mean intakes lower than EAR for niacin, pyridoxine, folic acid, pantothenic acid, vitamin $\mathrm{E}$, calcium, magnesium, phosphorus, potassium, sodium and zinc [26]. Comparing overweight and obese adolescent girls with others, overweight and obese adolescents had less carbohydrate, thiamin, niacin, iron and selenium intake $(P<0.05)$. In univariate analysis age, caste and literacy status of the subjects influenced significantly calcium intake. Significant association has been also observed between iron consumption and age, type of family, menstrual status, literacy status and nature of diet. Age was the only variable which was significantly associated with vitamin A consumption. The significant variables for consumption of vitamin $C$ have been total income of family (Rs./month), per capita income, socio economic status and mothers occupation. However on logistic regression significant variable(s) were sibling more than 7 for calcium, age and caste for iron and mother occupation and nature of diet for vitamin $C$. The scenario just described clearly reflect that their has been similarity in dietary pattern of adolescent girls to a considerable extent. The initiatives taken for overcoming micronutrients inadequacy by public sector has been grossly inadequate. Strategies and action at individual, family and community level for overcoming micronutrient inadequacy are particularly nonexistent. There is urgent need to move from strategic and conceptual framework to concerned efforts and action in this direction.

\section{CONCLUSION}

Micronutrients deficiency both in terms of average and percentage intake of RDAs prevailed in the study subjects irrespective of age group. This was quite significant for calcium, iron and vitamin A. In contrast to 
this average vitamin $\mathrm{C}$ intake was more than $80 \%$ of

RDA in all age groups.

\section{ACKNOWLEDGMENT}

Authors acknowledge Prof. G.P. Singh of the Department of Community Medicine, Institute of Medical Sciences, Banaras Hindu University, for statistical help.

\section{REFERENCES}

[1] World Health Organization. Young people's health-A challenge for society. Report of a WHO Study Group on young people and Health for All by the year 2000. Technical Report Series No. 731. Geneva: WHO 1986.

[2] Novella R. Adolescent Growth and Development. Virginia Polytechnic Institute and State University 2009; 1-5.

[3] Mishra CP, Reddy DCS, Tiwari IC. Growth pattern among Harijan and tribal preschool children. Indian Ped 1986; 23: $35-40$

[4] Mulugeta A, Fitsum H, Barbara Sr, Gideon K, Vincent L, Zenebe A, Mekonen Y, Girmay G. Samuel nutritional status of adolescent girls from rural communities of Tigray, Northern Ethiopia. Ethiop J Health Dev 2009; 23(1): 6-11. http://dx.doi.org/10.4314/ejhd.v23i1.44831

[5] Barnes HV. Physical growth and development during puberty. Med Clin North Am 1975; 59: 1305-1317.

[6] Wong DL, Wilson D, Whaley LF. Whaley \& Wong's nursing care of infants and children. 5th ed. St. Louis: Mosby 1995.

[7] Government of India : A strategic approach to reproductive, maternal, newborn, child and adolescent health $(\mathrm{RMNCH}+\mathrm{A})$ in India ; ministry of health \& Family Welfare Government of India January 2013.

[8] Gupta VM, Sen P. Adolescent Health. Indian J of Public Health $2001 ; 45(1): 3-7$.

[9] Working Group on Youth Affairs and Adolescents. Draft final report of working group on youth affairs and adolescents. The Development for formulation of 11th Five Year Plan (2007-2012) March 2007; Volume-I.

[10] Ministry of Youth Affairs \& Sports. Report of working group on adolescent and youth development, Deptt. of Youth Affairs, M/o YA\&S for formulation of 12th Five Year Plan (2012-17).Prepared by Department of Youth Affairs\& Sports, Government of India 2011; 1-133.

[11] Devadas RP, Easwaran PP. Intra-family food intake of selected rural households and food consumption patterns of pregnant women. Indian J Nutr Dietet 1986; 27: 237-245.

[12] Gopaldas T, Raghavan R, Kanani S. Nutritional impact of antiparasitic drugs, prophylactic vitamin $A$ and iron-folic acid on under privileged school girls in India. Nutr Res 1983; 3: 831-844.

http://dx.doi.org/10.1016/S0271-5317(83)80036-0

[13] Thakore B. A nutrition health status survey and nutritionhealth education intervention for underprivileged adolescent girls in Baroda. M.Sc. Thesis, Department of Foods and Nutrition. M.S. University of Baroda, Baroda 1989.
[14] Satyanarayana K, Naidu AN, Swaminathan MC, Rao BSN. Effect of nutrition deprivation in early childhood on later growth-A community study with out intervention. Am J Clin Nutr 1981; 34: 1636-1637.

[15] Pereira P, Mehta S. Physical growth in adolescent girls of upper socio-economic group in Varanasi. Indian J Med Res 1983, 77: 839-844

[16] National Institute of Nutrition. Report on diet and nutritional status of adolescents. NNMB. NNMB Technical Report No.20, NIN ICMR Hyderabad 2000; 20: 1-25.

[17] Frary CD, Johnson RK, Wang MQSO. Children and adolescents' choices of foods and beverages high in added sugars are associated with intakes of key nutrients and food groups. Adolesc Health 2004; 34(1): 56-60. http://dx.doi.org/10.1016/S1054-139X(03)00248-9

[18] Kurshed A, Mohammad A, Masud R, Sabina KTM, Alamgir A, Jamila B, Aminul HB. Dietary intake, physical activities and nutritional status of adolescent girls in an urban population of Bangladesh. Ibrahim Med Coll J 2010; 4(2): 78-82.

http://dx.doi.org/10.3329/imci.v4i2.6502

[19] Uma M I, Rachana M, Bhoite, Sharmistha R. An exploratory study on the nutritional status and determinants of malnutrition of urban and rural adolescent children (12-16) years of Vadodara city. International Journal Of Applied Biology And Pharmaceutical Technology 2011; 2(1): 102107.

[20] Parimalavalli R, Sangeetha M. Anthropometric measurements and nutrient intake of adolescent girls anthropologist 2011; 13(2): 111-115.

[21] Goel S, Kaur T, Gupta M. Increasing proclivity for junk food among overweight adolescent girls in district Kurukshetra, India. International Research Journal of Biological Sciences 2013; 2(3): 80-84.

[22] Registrar General and Census Commissioner, India: Census of India, Ministry of Home Affair, Government of India 2011. Available at http://censusindia. gov.in/

[23] Mishra CP, Jaya Krishna. Turbulence of adolescence, Indian J Prev Soc Med 2014; 45(1): 1-6.

[24] Mishra CP, Bhatnagar T, Choudhary S, Shukla KP, Mishra RN. Measuring SES through composite indicator: Monogram, Department of Community Medicine, Institute of Medical Sciences, Banaras Hindu University 2010.

[25] Gopalan C, Ramasastry BV, Balasubramanyam SC Narasinga RBS, Deosthale YG, Pant KC. Nutritive Value of Indian Foods. Hyderabad: National Institute of Nutrition 1989.

[26] Krishna J, Mishra CP. Correlates of macronutrients intake of adolescent girls in urban Varanasi. IJFANS 2014; 3(3): 6776.

[27] Bidad K, Anari SH, Tavasoli S, Nazemi L, Gholami N, Zadhush S, Moayeri H. Dietary intakes of adolescent girls in relation to weight status. Iranian J Publ Health 2008; 37(1): 114-118.

[28] Khan MR, Ahmed F. Physical status, nutrient intake and dietary pattern of adolescent female factory workers in urban Bangladesh. Asia Pac J Clin Nutr 2005; 14(1): 19-26.

[29] Shekhar A. Iron status of adolescents girls and its effect on physical fitness. The Indian J Nutr Dietet 2005; 42(10): 451456. 